\title{
Medium Development of Pleurotus Ostreatus by Using Korean Herb Medicine Materials
}

Ju-Gyo Jeong ${ }^{1}$, Chang-Yun Lee ${ }^{2}$ and Sang-Won Lee *

${ }^{1}$ Dept. of Pharmaceutical Engineering, Gyeongnam National University of Science and Technology, Jinju 660-758, Korea

${ }^{2}$ Greenpeace Mushroom Institute of Green Co, Cheongdo, Kyeongbuk, 714-853, Korea

Received March 12, 2012 /Revised April 5, 2012 /Accepted April 6, 2012

To reduce the production cost of Pleurotus ostreatus, discarded medicinal sludge was collected from oriental medical clinics to develop the Pleurotus ostreatus culture medium. According to the analysis of the proximate composition of the materials used in Korean herb medicine, the crude ash contents of Carthamus tinctrius L stem and Acanthopanax chiisanensis were $11.6 \%$ and $10.1 \%$ respectively, which were relatively higher than the $9.6 \%$ of the control medium, waste cotton. Crude protein was detected in $9.8 \%$ of the waste cotton medium, whereas it was detected in $14.9 \%, 13.9 \%, 13.4 \%$, and $11.5 \%$, of wild mugwort, Acanthopanax chiisanensis, medicinal sludge, and Carthamus tinctrius L stem, respectively, which are all higher than the control. The $\mathrm{pH}$ of medicinal sludges, wild mugwort, and Aacanthopanax chiisanenses ranged from 5.27 to 5.72 , which was similar to the $5.70 \mathrm{pH}$ value of waste cotton. In the case of addition concentration of each Korean herb medicine material influencing mycelial growth of the Pleurotus ostreatus, the $9 \%$ concentration was more favorable compared to that of $3 \%$ and $6 \%$. However, the addition of Korean herb medicine materials did not significantly affect the growth of $P$. tolaassi and Trichoderma sp. According to a field experiment that added $9 \%$ of medicinal sludge into the waste cotton medium, the mycelial growth of mushrooms was facilitated by approximately 2 days, and the mushroom yield was increased by 10 15\%. Furthermore, pileus and stipe of the mushrooms were even and superior in quality.

Key words : Pleurotus ostreatus, medicinal sludges, Korean herb medicines materials, waste cotton

\section{서 론}

느타리버섯(Pleurotus ostreatus)은 목재부후균류(백색부후 균)로서 고사목 및 그루터기에서 자생하는 식용버섯으로 우리 나라를 비롯한 세계 각국에 넓게 분포되어 있다[14]. 그 중에서 느타리버섯은 맛과 향이 좋고[8], 식생활 습관병의 예방에도 효과가 있으며, 혈액순환을 촉진하고, 요통, 관절염, 수족마비 의 치료, 불안정한 혈압의 조절 및 항암 효과가 있는 것으로 밝혀져 있으며[15], 단백질, 아미노산, 당류, 비타민 및 무기염 류 등 인체에 중요한 영양소를 함유하고 있는 것으로 알려져 있다[7,8].

우리나라에서 느타리버섯의 인공재배는 원목재배로 시작 되었으나, 원목자원의 구입이 어려울 뿐만 아니라 균사생장 기간이 길고 버섯의 수확시기도 봄, 가을로 한정되어 있기 때 문에 볏짚을 이용한 느타리버섯의 인공재배법이 개발됨으로 써 집약관리에 의한 버섯의 대량생산이 가능하게 되어 농가소 득에 크게 기여하였다[5,10,11,12,16]. 그러나 1980년대 중반 이 후부터는 농가의 기계화, 볏짚의 가축사료화 등으로 인하여

*Corresponding author

Tel : +82-55-751-3394, Fax : +82-55-751-3399

E-mail : swlee@gntech.ac.kr
볏짚을 대신하여 값싸게 구할 수 있는 폐면을 이용한 인공재 배법이 개발 보급되었다[2].

느타리버섯의 인공재배형태는 균상재배, 봉지재배, 병 재배 로 나눌 수 있으며 최근에는 시설재배사와 자동화를 이용한 대규모의 병 재배 농가가 늘어나고 있는 추세이다. 그리고 느 타리버섯 재배농가에서 버섯을 생산할 때 사용하는 배지의 원료측면에서 살펴보면 폐면은 거의 대부분 동남아시아 및 캐나다 등의 외국으로부터 수입에 의존하고 있기 때문에 외화 의 낭비뿐만 아니라 환율인상 등의 요인으로 버섯생산 단가가 상승하여 농가소득 감소의 주원인으로 이어지고 있다. 이러한 문제점을 해결하기 위해서 버섯의 배지원료인 볏짚 및 폐면 등을 대신할 수 있는 값싼 배지재료의 발굴이 절실히 필요하 기 때문에 많은 연구자들에 의해서 농산부산물 및 산업폐기물 등을 버섯의 염가 배지자원으로 이용하기 위한 연구가 활발히 이루어지고 있다[3,4,6,9,13].

지리산을 끼고 있는 서부경남지역은 옛날부터 한방약초의 재배가 활성화되어 다양한 약초들이 대량 생산되고 있지만 최근, UR 및 FTA체결 등으로 중국으로부터 값싼 한방약초의 수입이 급증함에 따라 약초의 판매부진으로 농가소득이 급격 하게 감소되고 있다. 그리고 시내의 한의원 및 탕재원 등에서 대량 배출되고 있는 한방슬러지의 대부분은 퇴비 등으로 처리 
되고 있는 실정이다. 그렇기 때문에 본 연구에서는 한방약초 및 한방슬러지를 느타리버섯 배지의 부원료나 첨가제로 이용 하여 느타리버섯의 생산단가를 절감할 목적으로 평판배지 및 폐면배지에서 한방재료가 느타리버섯의 균사성장에 미치는 영향 및 첨가농도 등을 검토한 다음 버섯 재배농가에서 직접 느타리버섯의 생산에 접목하여 한방슬러지의 배지개발 가능 성을 검토하였다.

\section{재료 및 방법}

\section{공시균주 및 배지}

본 실험에 사용하는 느타리버섯(Pleurotus ostreatus)과 느타 리버섯에 푸른곰팡이병을 일으키는 Trichoderma virens KCCM 11246 곰팡이는 농촌진흥청에서 분양 받아 사용하였고, 세균 성 갈색무늬병을 일으키는 Pseudomonas tolaasii ATCC-33618 는 경남과학기술대학교 제약공학과 생물공학 실험실에 보존 중인 것을 사용하였다. 느타리버섯 및 곰팡이의 보존을 위한 배지는 PDA (potato dextrose agar), 세균의 보존배지는 NA (nutrient agar)배지를 사용하였다. 느타리버섯의 재배를 위한 폐면배지는 산청느타리버섯 연합회의 버섯농가에서 사용하 는 배지를 사용하였다.

\section{시험재료}

실험에 사용한 두충 및 지리오갈피 등은 농가에서 직접 구 입하여 사용하였고, 홍화대는 홍화를 수확하고 폐기처리하기 위하여 쌓아둔 홍화줄기를 구입하여 사용하였다. 한방슬러지 는 탕제원 및 인근의 한의원에서 폐기처리 되는 것을 무작위 로 수거하여 사용하였다. 야생 쑥은 지리산 기슭의 야산에서 10 월 말에 채취하여 사용하였다. 그리고 이 이외의 폐면 및 볏짚 등은 지리산 산청느타리버섯연합회에서 느타리버섯을 재배할 때 사용하는 재료를 기준으로 하였다.

\section{일반성분 분석}

한방약재의 일반성분 분석은 $\mathrm{AOAC}$ 법[1]에 의하여 3 회 반 복 실험하여 통계처리 하였다. 조회분은 $550^{\circ} \mathrm{C}$ 직접회화법, 조지방은 soxhlet 지방추출법, 조단백은 micro-Kjeldahl법으 로 측정하였다.

\section{한방약재 첨가 평판배지}

두충, 지리오갈피, 홍화대, 야생 쑥 및 한방슬러지는 1 2 $\mathrm{cm}$ 길이로 절단한 다음 완전히 건조시켜 $80 \mathrm{mesh}$ 로 분쇄한 후 0 9\%(w/w) 농도범위로 첨가하고 agar를 $1.5 \%$ 첨가하여 $120^{\circ} \mathrm{C}, 15$ 분 멸균한 다음 petri dish에 분주하여 평판배지를 제조하였다. 제조한 평판배지에 느타리버섯 종균의 접종은 코 르코볼 No. 3(직경 $5 \mathrm{~mm}$ )로 원통 블록형으로 접종하여 $25^{\circ} \mathrm{C}$ 에서 배양하면서 버섯균사의 성장상태를 관찰하였다.

\section{한방약재 첨가 폐면배지}

한방약재를 첨가한 폐면배지에서 느타리버섯의 균사성장 상태를 검토하기 위하여 버섯재배 농가에서 발효를 끝낸 폐면 배지에 여러 종류의 한방약재 및 한방슬러지를 각각 $9 \%$ 씩 첨 가하여 잘 혼합 다음 $180 \mathrm{ml}$ 유리병에 충진시켜 $121^{\circ} \mathrm{C}, 30$ 분 멸균시킨 후, 미리 배양하여 준비해둔 느타리버섯의 액체종균 $10 \mathrm{ml}$ 를 배지 상층부에 균일하게 접종하여 $25^{\circ} \mathrm{C}$ 의 항온기에서 8 일 동안 배양하면서 느타리버섯 균사의 성장 길이를 측정하 였다. 대조구로는 버섯재배 농가에서 사용하는 폐면배지를 그 대로 사용하였다.

\section{한방약재의 $\mathrm{pH}$ 측정}

80 mesh로 분쇄한 각 한방약재의 시료 $10 \mathrm{~g}$ 에 증류수 90 $\mathrm{ml}$ 를 첨가하고 실온에서 2시간 동안 천천히 교반시킨 다음 $121^{\circ} \mathrm{C}$ 에서 20 분 동안 멸균한 후 여과지로 여과한 여액의 $\mathrm{pH}$ 를 측정하였다.

\section{버섯병원균의 생육}

$300 \mathrm{ml}$ 삼각플라스크에 $9 \%$ 한방약재 및 한방슬러지의 각 추출용액 $100 \mathrm{ml}$ 를 첨가하고 $121^{\circ} \mathrm{C}, 15$ 분 멸균하여 제조한 액 체배지에 버섯재배 시 갈반병을 유발하는 P. tolaassi의 전배양 액 $5 \mathrm{ml}$ 을 접종한 다음 $37^{\circ} \mathrm{C}, 20$ 시간 배양한 후 $660 \mathrm{~nm}$ 에서 배양액의 흡광도를 측정하였다. 대조구로는 LB배지를 사용하 였다. 푸른곰팡이 병을 유발하는 T. virens의 생육에 미치는 영향은 한방약재 및 한방슬러지의 각 분말 $9 \%$ 와 $1.5 \%$ 의 agar 을 첨가하여 제조한 평판배지 중앙에 곰팡이를 코르코볼 No. 3 (직경 $5 \mathrm{~mm}$ )로 접종하고 $30^{\circ} \mathrm{C}$ 에서 배양하면서 곰팡이의 균 사성장 정도를 관찰하였다.

\section{한방재료 배지의 현장적용 시험}

느타리버섯 생산을 위한 현장적용 실험은 지리산 산청느타 리버섯연합회원 중 6 농가의 신청을 받아 폐면배지에 $9 \%(\mathrm{~W} / \mathrm{W})$ 한방슬러지를 첨가하여 2월 7월에 걸쳐 느타리버 섯의 재배를 행하였다. 배지의 발효는 폐면 $1,720 \mathrm{~kg}$, 볏짚 100 $\mathrm{kg}$ 및 한방슬러지 $180 \mathrm{~kg}$ 을 잘 혼합한 다음 버섯재배농가에서 폐면배지를 발효시키는 종래의 방법에 준하여 발효시켰다. 생 산된 느타리버섯의 품질은 도매시장에 출하하는 느타리버섯 갓의 크기와 버섯대의 굵기를 기준으로 특품, 상품 및 하품으 로 나누어서 평가하였다. 그리고 단위면적당 느타리버섯의 생 산량 검토는 재배사 1 동 $\left(132 \mathrm{~m}^{2}\right)$ 에서 생산되는 느타리버섯 특 품, 상품 및 하품의 박스 $(4 \mathrm{~kg})$ 수로 나타내었다.

\section{결과 및 고찰}

\section{일반성분 분석}

한방약재 및 한방슬러지의 일반성분을 검토하여 Table 1에 
Table 1. Proximate composition of the Korean herb medicines materials

\begin{tabular}{lcccc}
\hline Materials & Crude ash (\%) & Crude fat (\%) & Crude protein (\%) & Crude fiber (\%) \\
\hline Waste cotton & $9.6 \pm 1.2$ & $1.9 \pm 0.6$ & $9.8 \pm 0.3$ & $37.5 \pm 1.6$ \\
Medicinal sludge & $5.9 \pm 0.9$ & $10.1 \pm 0.5$ & $13.4 \pm 1.4$ & $18.2 \pm 1.8$ \\
Eucommia ulmoides & $2.5 \pm 1.4$ & $3.5 \pm 1.1$ & $2.6 \pm 0.7$ & $66.2 \pm 1.3$ \\
Carthamus tinctorius L stem & $11.6 \pm 1.3$ & $3.4 \pm 0.9$ & $11.5 \pm 0.4$ & $52.1 \pm 1.5$ \\
Wild mugwort & $8.3 \pm 0.9$ & $6.9 \pm 0.5$ & $14.9 \pm 1.1$ & $30.4 \pm 1.9$ \\
Acanthopanax chiisanensis & $10.1 \pm 0.8$ & $3.1 \pm 0.7$ & $13.9 \pm 1.6$ & $20.6 \pm 1.6$ \\
\hline
\end{tabular}

나타내었다. 대조구로는 느타리버섯을 재배할 때 배지로 사용 하는 폐면을 사용하였다. 조회분 함량은 홍화대와 지리오갈피 가 $11.6 \%$ 와 $10.1 \%$ 를 나타내어 대조구인 폐면의 $9.6 \%$ 보다 높 게 나타났으나 야생 쑥, 한방슬러지 및 두충은 각각 $8.3 \%, 5.9 \%$ 및 $2.5 \%$ 로 대조구보다 낮게 나타났다. 조지방 함량은 모든 시 험구에서 대조구인 폐면보다 높게 나타났다. 그 중에서도 한 방슬러지 및 야생 쑥에서는 각각 $10.1 \%$ 및 $6.9 \%$ 로 측정되어 대조구보다 약 4 5배 높게 나타났다. 그리고 두충, 홍화대 및 지리오갈피에서는 각각 $3.5 \%, 3.4 \%$ 및 $3.1 \%$ 로 폐면보다 약간 높게 나타났다. 조단백 함량은 폐면배지에서는 $9.8 \%$ 로 검출되 었으나 야생 쑥, 지리오갈피, 한방슬러지 및 홍화대에서는 각 각 $14.9 \%, 13.9 \%, 13.4 \%$ 및 $11.5 \%$ 로 대조구보다 높게 나타났 다. 조섬유 함량은 대조구인 폐면배지는 $37.5 \%$ 를 나타내었으 나 두충과 홍화대는 $66.2 \%$ 와 $52.1 \%$ 를 나타내어 대조구보다 높게 검출되었고, 그 외의 시료에서는 약 $20 \%$ 전후의 함량을 나타내었다.

\section{$\mathrm{pH}$}

한방약재 및 한방슬러지 용액의 $\mathrm{pH}$ 를 측정하여 Fig. 1에 나타내었다. 한방슬러지, 야생쑥 및 지리오갈피 여과액의 $\mathrm{pH}$ 는 5.27 5.72 범위를 나타내어 대조구인 폐면이 나타낸 $\mathrm{pH}$ 5.70 과 거의 같은 수준의 $\mathrm{pH}$ 를 나타내었다. 그러나 두충과 홍 화대는 각각 $\mathrm{pH} 4.58$ 과 $\mathrm{pH}$ 6.69를 나타내어 대조구보다 약간 낮거나 높게 나타났다. Cheong 등[3]은 팽이버섯을 재배할 때 배지 주성분인 미송톱밥의 $\mathrm{pH}$ 가 5.1인데 비하여 미강은 $\mathrm{pH}$ 6.3 , 계란껍질은 $\mathrm{pH}$ 6.8로 너무 높아 이들을 단독으로 사용하 는 것보다 적당한 비율로 혼합하여 사용할 것을 권장하였다.

\section{한방재료 첨가농도의 영향}

한방슬러지 등의 첨가농도가 느타리버섯의 균사성장에 미 치는 영향을 검토하여 Fig. 2에 나타내었다. 대조구로는 한방 슬러지를 첨가하지 않고 agar 만으로 제조한 평판배지를 사용 하였다. 각 시험구의 대조구에서는 느타리버섯의 균사성장이 전혀 이루어지지 않았으나 한방약재 및 한방슬러지를 3 9\% 농도 범위로 첨가한 시험구에서는 느타리버섯의 균사성장이 왕성하게 이루어졌다. 그 중에서도 한방슬러지, 홍화대 및 오 갈피를 첨가한 시험구에서 느타리버섯의 균사성장이 매우 빠

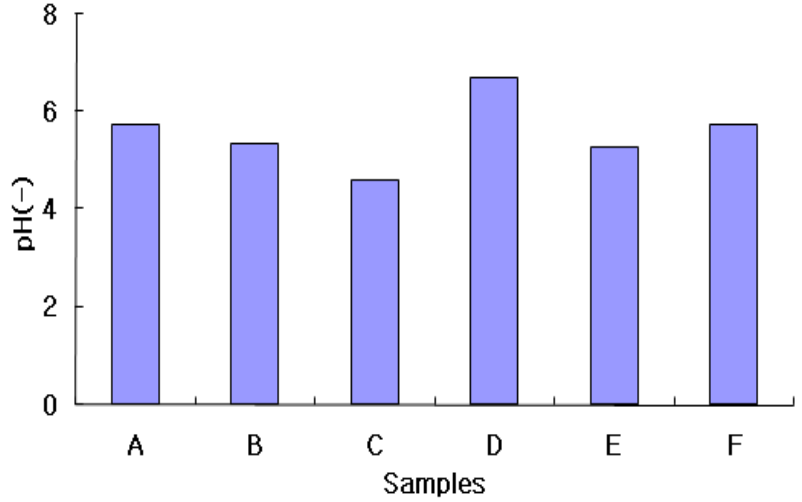

Fig. 1. $\mathrm{pH}$ of Korean herb medicines material. A: Waste cotton, B: Medicinal sludge, C: Eucommia ulmoides, D: arthamus tinctrius L stem, E: Wild mugwort, F: Acanthopanax chiisanensis

르면서 조밀하게 형성되었다. 그러나 두충을 첨가한 시험구 (Fig. $2 \mathrm{C}$ )에서는 두충의 첨가농도에 관계없이 균사성장이 전 혀 이루어지지 않았다. 그리고 각 한방재료의 첨가농도는 $3 \%$ 및 $6 \%$ 의 첨가보다 $9 \%$ 의 첨가구에서 느타리버섯 균사의 성장 및 조밀도가 양호하였다. 그러나 한방재료를 $9 \%$ 이상 첨가하 여 평판배지를 제조할 때는 배지 중의 수분을 첨가하는 한방 재료의 분말이 거의 대부분 흡수하여 평판배지의 분주가 매우 곤란하였다. 이상의 결과로 한방재료의 첨가농도는 $9 \%$ 가 적 당한 것으로 판단된다. Cheong 등[3]은 톱밥배지에 계란껍질 을 5 15\% 첨가함으로써 버섯배지의 물성을 개선하였다고 보 고하였다. 또한 Choi 등[4]은 홍화대를 첨가한배지에서 팽이 버섯의 균사생육을 검토한 결과 대조구에 비하여 균사생장 길이를 $8 \mathrm{~mm}$ 촉진시켰으며 배양완성일은 1 일 단축, 배양완성 율은 $3.1 \%$ 증가시켰다고 보고하였다. Hong 등[6]은 느타리버 섯의 균사체 성장에 oil 첨가효과를 검토한 결과 cotton seed oil을 $2.5 \%(\mathrm{v} / \mathrm{v})$ 첨가 하였을 때 균체량이 대조구에 비하여 4 배 정도 증가하였다고 보고하였다.

\section{한방재료가 버섯질병균에 미치는 영향}

한방약재 및 한방슬러지를 버섯의 배지로 사용하였을 때 버섯의 재배 시 빈번하게 발생하는 세균성 갈반병과 푸른곰팡 이 병을 유발하는 원인균의 생육에 미치는 영향을 검토하여 

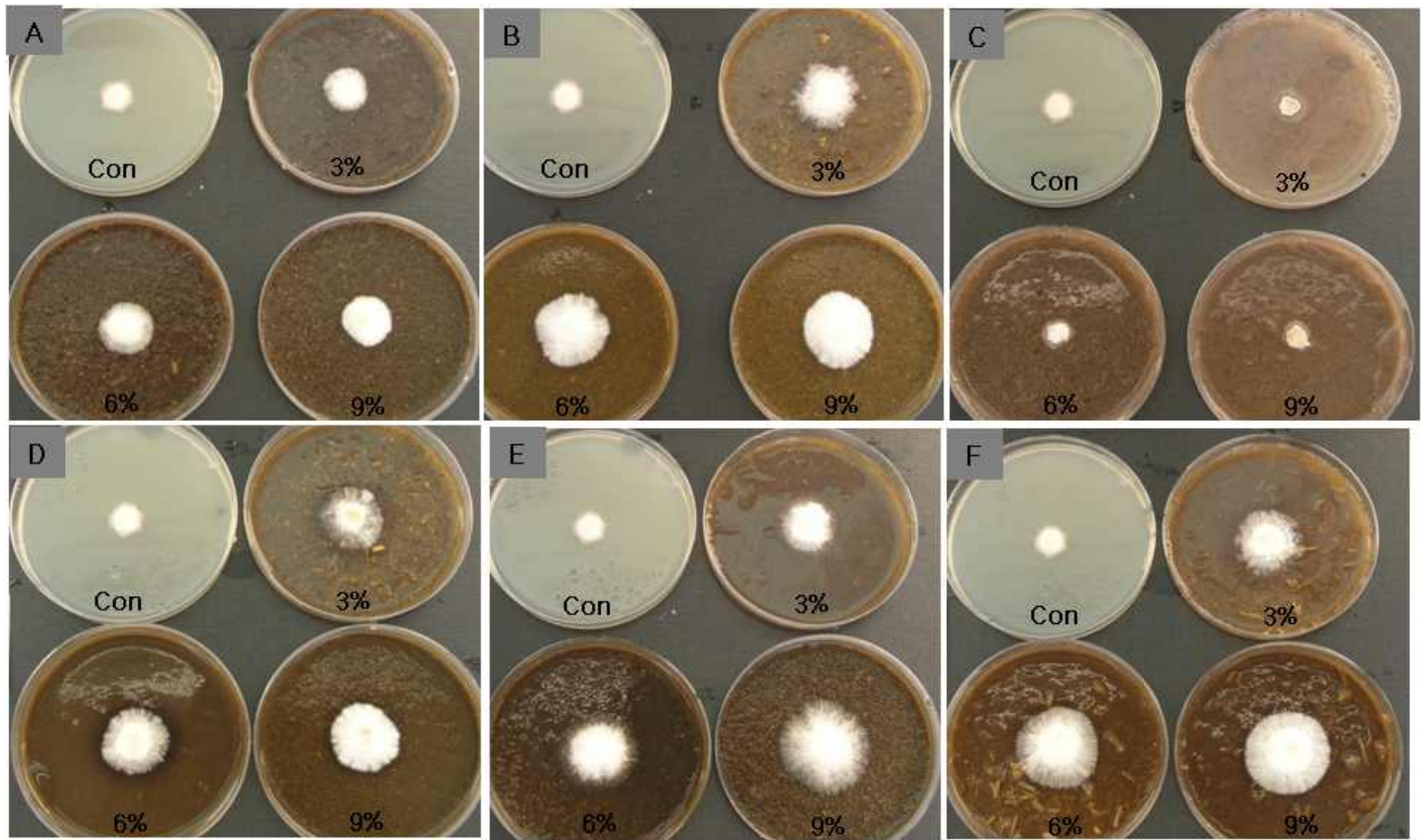

Fig. 2. Effects of Korean herb medicines on the growth of $P$. astreatus mycelium. A: Waste cotton, B: Medicinal sludge, C: Eucommia ulmoides, D: Carthamus tinctrius L stem, E: Wild mugwort, F: Acanthopanax chiisanensis.

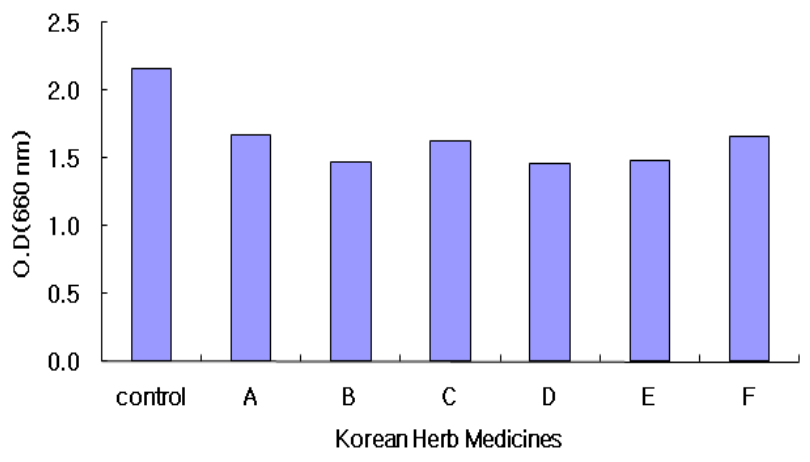

Fig. 3. Effects of Korean herb medicines material media on the growth of $P$. tolaassi. Con: LB, A: Waste cotton, B: Medicinal sludge, C: Eucommia ulmoides, D: Carthamus tinctrius L stem, E: Wild mugwort, F: Acanthopanax chïsanensis.

Fig. 3에 나타내었다. 대조구로는 LB배지와 폐면을 동일하게 처리하여 사용하였다. $\mathrm{LB}$ 배지에서는 P. tolaassi 세균이 잘 생 육하였으며 한방약재 및 한방슬러지의 추출물로 제조한 배지 에서는 폐면을 사용한 시험구와 거의 대등하게 생육하였다. 이상의 결과로 한방약재 및 한방슬러지는 세균성 갈반병을 유발하는 P. tolaassi의 생육에는 크게 영향을 미치지 못하는 것으로 판단된다. 결과는 나타내지 않았지만 푸른곰팡이 병을 유발하는 Trichoderma sp. 곰팡이의 균사 생육에도 크게 영향 을 미치지 못하는 것으로 나타났다.
한방재료가 버섯균사 성장에 미치는 영향

지금까지의 연구결과를 바탕으로 느타리버섯 재배농가에 서 발효시킨 폐면배지에 여러 종류의 한방재료를 $9 \%$ 씩 첨가 하여 잘 혼합한 배지를 $180 \mathrm{ml}$ 유리병에 충진시켜 $121^{\circ} \mathrm{C}, 30$ 분 멸균시킨 다음, 느타리버섯의 액체종균 $10 \mathrm{ml}$ 를 배지 상층부 에 균일하게 접종한 후 $25^{\circ} \mathrm{C}$ 의 항온기에서 8 일 동안 배양한 결과를 Table 2에 나타내었다. 대조구로는 버섯재배 농가에서 사용하는 폐면배지를 그대로 사용하였다. Table 2에서 보는바 와 같이 종균을 접종하고 2 일 배양하였을 때 폐면배지에서는 느타리버섯의 균사성장이 $10 \mathrm{~mm}$ 정도에 지나지 않았다. 그러 나 두충을 첨가한 시헌구에서는 약 $15 \mathrm{~mm}$ 성장하여 약간 미 약하였으나 다른 시험구에서는 25 37 mm로 매우 왕성한 균 사성장을 보여 느타리버섯 재배에 한방약재의 사용 가능성을 시사하였다.

Table 2. Effects of medicinal herbs and sludge on the growth of $P$. ostreatus mycelium

\begin{tabular}{|c|c|c|c|c|}
\hline \multirow{2}{*}{ Substrate Culture days } & \multicolumn{4}{|c|}{ Mycelial growth (mm) } \\
\hline & 2 days & 4 days & 6 days & 8 days \\
\hline Waste cotton & 10 & 18 & 26 & 41 \\
\hline Medicinal sludge & 28 & 62 & 80 & 90 \\
\hline Eucommia ulmoides & 15 & 30 & 45 & 50 \\
\hline Carthamus tinctorius $\mathrm{L}$ stem & 25 & 53 & 74 & 90 \\
\hline Wild mugwort & 31 & 55 & 79 & 90 \\
\hline Acanthopanax chïsanensis & 33 & 60 & 81 & 90 \\
\hline
\end{tabular}


그리고 배양일수가 길어짐에 따라 느타리버섯 균사성장의 차이는 더욱더 현저하게 나타났으며, 배양 6 일 이후에는 지리 오갈피 및 한방슬러지 첨가 시험구 유리병은 배지 전체가 느 타리버섯 균사로 덮였었다. 이상의 결과로 여러 종류의 한방 약재 및 한방슬러지를 느타리버섯 배지의 첨가제로 사용할 경우 느타리버섯 균사 성장이 촉진되는 것을 확인하였다. 특 히 무작위로 채취한 한방슬러지는 한의원 및 탕재원 등에서 수거가 용이하고 전처리 없이 그대로 버섯배지로 사용할 수 있기 때문에 느타리버섯 재배농가의 노동력 절약뿐만 아니라 버섯생산 단가를 낮추는데 도움이 될 것으로 생각된다. Lee 등 [9]은 마늘껍질을 이용한 느타리버섯의 인공재배에서 톱밥 과 미강을 $8: 2$ 로 혼합하여 제조한 배지에서는 버섯균사 성장 이 $24 \mathrm{~mm}$ 정도였으나 톱밥, 미강 및 마늘껍질을 5:2:3으로 혼 합하여 제조한 배지에서는 버섯균사성장이 $27 \mathrm{~mm}$ 로 양호하 였다고 보고하면서 농산폐자원의 이용측면에서 느타리버섯 을 값싸게 생산할 수 있을 것으로 보고하였다.

\section{느타리버섯 생산}

한방슬러지 $9 \%$ 첨가배지를 사용하여 느타리버섯 재배농가 에서 현장실험을 행한 결과를 Table 3에 나타내었다. 배지의 살균 및 발효를 행할 때부터 1주기 버섯을 수확할 때까지 막사 내부에서는 한방약재의 냄새를 느낄 수 있었으나 막사 내부의 환기 및 통풍 등으로 인하여 1 주기 이후로는 한방약재의 냄새 가 서서히 약해지기 시작하였다. 한방슬러지 첨가배지에서는 버섯의 균사생장이 대조구인 폐면배지에서 보다 약 2 3일
정도 빠르게 나타났고, 종균의 활착율도 높게 나타났다. 그리 고 버섯의 수확량은 폐면배지에서 보다 10 15\% 정도 증수되 는 것으로 확인되었다. 그러나 기온이 높아지는 6월 및 7월의 버섯재배에서는 6 주기 이후부터 배지가 급격하게 쇠퇴하여 갈반병 등의 발생이 약간 관찰되었다. 이러한 결과는 한방슬 러지의 첨가로 배지 중의 영양가가 높아져 높은 기온으로 인 한 다른 잡균의 번식이 용이하기 때문으로 사료되었다. 느타 리버섯의 품질은 폐면배지에서 생산된 느타리버섯 보다 한방 배지에서 생산된 버섯의 대 및 갓 등이 균일하여 우수한 것으 로 나타났고 버섯의 전체적인 수확량에 있어서도 약 $10 \%$ 증가 하였다. 이상의 결과로 본 연구에서 수행한 한방슬러지를 이 용한 한방 느타리버섯의 상품화는 충분히 가능한 것으로 사료 되었다. Cheong 등[3]은 톱밥배지 제조 시에 계란껍질을 $15 \%$ 첨가함에 따라 배지의 물성이 개선되고 배지 중의 인과 칼슘 함량이 높아 생산된 버섯의 품질이 향상되었으며 버섯자실체 의 수량이 $23 \%$ 증수되었다고 보고하였다. Hong 등[6]은 농산 물 및 산업폐기물을 이용하여 느타리버섯을 재배한 결과 볏짚 의 biological efficiency (B.E.)가 $36.4 \%$ 였으며, 땅콩박은 $32.6 \%$ 로 나타났으나 볏짚과 맥주박을 1:1로 혼합하였을 경우는 B.E. 가 $109.6 \%$ 를 나타내었고, 땅콩박과 맥주박을 1:1로 혼합했을 때는 B.E.가 $74.5 \%$ 를 나타내었다고 보고하였다.

\section{경제성 분석}

느타리버섯 재배농가에서 버섯을 재배할 때 한방슬러지 첨 가배지를 사용할 경우 얻어지는 경제적 효과를 산출하여

Table 3. Comparison of the quality of the $P$. ostreatus produced in the waste cotton and $9 \%$ medicinal sludge media

\begin{tabular}{|c|c|c|c|c|c|}
\hline \multirow[t]{2}{*}{ Substrate } & \multirow[t]{2}{*}{ Mycelial growth (days) } & (One & $\begin{array}{l}\text { yster Mushroom } \\
\left.\mathrm{ck} / 132 \mathrm{~m}^{2}\right)(4 \mathrm{k}\end{array}$ & & \multirow[t]{2}{*}{ Total } \\
\hline & & Excellent quality ${ }^{{ }^{1}}$ & Good quality $^{* 2}$ & Low quality ${ }^{* 3}$ & \\
\hline Waste cotton (Control) & 25 & 250 & 100 & 50 & 400 Boxes \\
\hline Medicinal sludge $(9 \%)$ & 23 & 280 & 110 & 60 & 450 Boxes \\
\hline
\end{tabular}

${ }^{{ }^{* 1}}$ Mushroom products with a pileus of $2.6 \sim 2.8 \mathrm{~mm}$ in diameter and a straight stipe of $1.2 \sim 1.7 \mathrm{~mm}$ in diameter.

${ }^{* 2}$ Mushroom products with a pileus of $2.4 \sim 2.6 \mathrm{~mm}$ in diameter and an unstraightened stipe of $1.2 \sim 1.7 \mathrm{~mm}$ in diameter.

${ }^{* 3}$ Mushroom products with a pileus of less than $2.4 \mathrm{~mm}$ in diameter and $2.8 \mathrm{~mm}$ in height, and a stipe of less than $1.2 \mathrm{~mm}$ in diameter.

Table 4. The economic effects of the waste cotton and $9 \%$ medicinal sludge media

\begin{tabular}{|c|c|c|c|c|}
\hline \multirow[b]{2}{*}{ Substrate } & \multirow[b]{2}{*}{$\begin{array}{l}\text { Waste cotton } \\
\text { (250won/kg) }\end{array}$} & \multicolumn{3}{|c|}{ Yield of Oyster Mushroom and price $(4 \mathrm{~kg} / \mathrm{Box})$} \\
\hline & & $\begin{array}{l}\text { Excellent quality } \\
\text { (20,000 won/Box) }\end{array}$ & $\begin{array}{l}\text { Good quality }{ }^{* 4} \\
(15,000 \text { won/Box })\end{array}$ & $\begin{array}{l}\text { Low quality }{ }^{{ }^{5}} \\
(10,000 \text { won/Box })\end{array}$ \\
\hline Control $^{* 1}$ & $2,000 \mathrm{~kg}$ & 250 Box & 100 Box & 50 Box \\
\hline Experiment $^{* 2}$ & $1,800 \mathrm{~kg}$ & 280 Box & 110 Box & 60 Box \\
\hline Effect of Economics (won) & 50,000 won & 600,000 won & 150,000 won & 100,000 won \\
\hline
\end{tabular}

${ }^{{ }_{1}}$ Waste cotton, ${ }^{* 2}$ Medium containing 9\% medicinal sludge was added (one block/ $132 \mathrm{~m}^{2}$ ).

${ }^{* 3}$ Mushroom products with a pileus of some $2.6 \sim 2.8 \mathrm{~mm}$ in diameter and a straight stipe of $1.2 \sim 1.7 \mathrm{~mm}$ in diameter.

${ }^{*}$ Mushroom products with a pileus of $2.4 \sim 2.6 \mathrm{~mm}$ in diameter and an unstraightened stipe of $1.2 \sim 1.7 \mathrm{~mm}$ in diameter.

${ }^{* 5}$ Mushroom products with a pileus of less than $2.4 \mathrm{~mm}$ in diameter and $2.8 \mathrm{~mm}$ in height, and a stipe of less than $1.2 \mathrm{~mm}$ in diameter. 
Table 4 에 나타내었다. 40 평 버섯 재배사 1 동을 기준으로 할 때 폐면배지의 절약은 $200 \mathrm{~kg}$ 으로 금액으로 환산하면 45,000 원 정도 절감 할 수 있을 것으로 예상된다. 그리고 2008년 7 8 월의 느타리버섯 경매가격으로 계산하여 버섯의 생산량에서 얻어지는 경제적 효과는 특품에서 600,000원, 상품에서 150,000 원, 하품에서 100,000 원 정도 수익증대를 올릴 수 있어 모두 합산하면 약 900,000 원 정도의 농가 소득증대에 기여할 것으로 생각된다. 또한 느타리버섯 재배 농가에서는 일반적으 로 40 평의 버섯 재배사를 3 동씩은 가지고 있고, 1 년에 2 회의 느타리버섯을 재배하는 것으로 볼 때 1 가구당 1 년에 얻어지는 농가소득은 $5,400,000$ 원 정도 되는 것으로 산출된다.

\section{감사의 글}

본 연구는 2009년도 농림수산식품평가원의 지원과 경남과 학기술대학교 기성회 연구비 지원으로 수행된 연구결과의 일 부이며 이에 감사드립니다.

\section{References}

1. AOAC. 1990. Official methods of analysis. 15th (eds.), Association of Official Analytical Chemists, Washington D.C., USA.

2. Chang, S. T. and Miles, P. G. 1989. Edible mushroom and their cultivation. pp. 189-223, CRC Press, Florida.

3. Cheong, J. C., Kim, G. P., Kim, H. K., Kim, Y. H., Cha, D. Y. and Chung, B. K. 1995. Effect of addition of eggshell to sawdust substrate on the growth and development of winter mushroom, Flammulina velutipes. Kor. J. Mycol. 23, 226-231.

4. Choi, I. Y., Kim, K. T., Choi, J. S., Na, C. S. and Lee, S. T. 1998. Effect of addition of Cathamus tinctorius, Coptis japonica and Asarum sieboldii to sawdust substrate on the growth and development of winter mushroom, Flammulina velutipes. Kor. J. Plant. Res. 11, 131-135.

5. Chung, H. C. 1983. Studies on the fermentation of rice straw substrates for cultivation of Pleurotus astreatus. Kor. J. Mycol. 11, 177-181.

6. Hong, B. S., Kim, S. J., Song, C. H., Hwang, S. Y. and Yang, H. C. 1992. Development of substrate and cultural method for the cultivation of Pleurotus sajor-caju. Kor. J. Mycol. 20, 354-359.

7. Jonninson, M. W. 1959. Chemical and vitamin composition of the mycelium of wood rotting Basidiomycetes. Mushroom Sci. 4, 183-185.

8. Kalberer, R. and Kunsch, U. 1974. Amino acid composition of the oyster mushroom (Pleurotus ostreatus). Lebensn $U$. Technol. 7, 242-244

9. Lee, S. S., Kim, S. K., Lee, T. S. and Lee, M. W. 1997. Cultivation of oyster mushroom using the garlic peel as an agricultural by-product. Kor. J. Mycol. 25, 268-275.

10. Lelly, J. 1972. Pleurotus astreatus has great possibilities, Mushroom Growers Assoc. Bull. 271, 311-313.

11. Park, Y. H., Go, S. J. and Kim, D. S. 1975. Studies on the cultivation of oyster mushroom, Pleurotus ostreatus (Fr.) Quel. using rice straw as growing substrate I. Experiment on the development of growing substrates. Report O.R.D. 17 (S.F.P. \& M), 103-107.

12. Park, Y. H., Go, S. J. and Chang, H. C. 1977. Studies on the cultivation of oyster mushroom, Pleurotus astreatus (Fr.) Quel. using rice straw as growing substrate II. The effect of heat treatment to the substrate. Report O.R.D. 19 (S.F.P. \& M), 93-97.

13. Ryu, J., Lee, G. J., Jung, G. T., Na, J. S. and Hwang, C. J. 1996. Study on the media development of Pleurotus astreatus by waste cotton stuff. Kor. J. Mycol. 24, 176-179.

14. Shin, G. C. 1987. Harmful fungi associated with rice straw media for growing of oyster mushroom, Pleurotus ostreatus. Kor. J. Mycol. 15, 92-98.

15. Yoshioka, Y., Tabeta, R., Saito, H., Ueharo, N. and Fukuoka, F. 1985. Antitumor polysaccharides from $P$. astreatus (Fr.) Quel. Isolation and structure of a $\beta$-glucan. Carbohydrate Res. 140, 93-100.

16. Zadrazil, F. 1974. The ecology and industrial production of Pleurotus ostreatus, P. florida, P. cornucopiae, and P. eryngii. Mushroom Sci. 9, 594-653. 


\section{초록 : 한방재료를 이용한 느타리버섯의 배지개발}

정주교 ${ }^{1} \cdot$ 이창윤 ${ }^{2} \cdot$ 이상원 $^{1} *$

( ${ }^{1}$ 경남과학기술대학교 제약공학과, ${ }^{2}$ 그린합명회사 그린피스 버섯연구소)

느타리버섯의 생산단가를 절감할 목적으로 한의원 등에서 폐기처리 되고 있는 한방슬러지를 수거하여 느타리 버섯 배지의 개발을 행하였다. 한방재료의 일반성분을 검토한 결과 조회분 함량은 홍화대와 지리오갈피가 $11.6 \%$ 와 $10.1 \%$ 를 나타내어 대조구인 폐면의 $9.6 \%$ 보다 높게 나타났다. 조지방 함량은 모든 시험구에서 대조구인 폐면 보다 높게 나타났다. 조단백 함량은 폐면배지에서는 $9.8 \%$ 로 검출되었으나 야생 쑥, 지리오갈피, 한방슬러지 및 홍화대에서는 각각 $14.9 \%, 13.9 \%, 13.4 \%$ 및 $11.5 \%$ 로 대조구보다 높게 나타났다. 한방슬러지, 야생쑥 및 지리오갈 피의 $\mathrm{pH}$ 는 $5.27 \sim 5.72$ 범위로 폐면이 나타낸 $\mathrm{pH} 5.70$ 과 거의 같은 수준이었다. 느타리버섯의 균사 성장에 미치는 각 한방재료의 첨가농도는 3\% 및 $6 \%$ 의 첨가보다 $9 \%$ 의 첨가구에서 느타리버섯 균사의 성장이 양호하였다. 그러 나 한방재료의 첨가는 P. tolaassi의 생육 및 Trichoderma sp.의 생육에는 크게 영향을 미치지 못하였다. 폐면배지에 $9 \%$ 의 한방슬러지를 첨가하여 실시한 현장 실험결과 버섯의 균사생장은 폐면배지에서 보다 약 2 3일 정도 빠르 게 나타났고, 버섯의 수확량은 10 15\% 정도 증수되었으며 또한 버섯의 대 및 갓 등이 균일하고 우수하였다. 